\title{
Program Pendidikan Masyarakat Dan Kebijakan Pembangunan Sosial Ekonomi Menuju Sistem Peternakan Masa Depan
}

\author{
Wahidin \\ Program Studi Pendidikan Luar Sekolah, Fakultas Keguruan dan Ilmu \\ Pendidikan, Universitas Palangka Raya, Indonesia \\ Email :wahidin.dikdas67@gmail.com
}

Diterima: 25-09-2021; Diperbaiki:01-10-2021; Disetujui:02-10-2021

\begin{abstract}
ABSTRAK
Pertumbuhan ekonomi Indonesia diramalkan akan terus meningkat pada tahun- tahun mendatang, dan pertumbuhan ini akan memacu peningkatan konsumsi, antara lain konsumsi hasilhasil peternakan. Pada sisi lain, suplai hasil peternakan dalam negeri seperti daging dan susu masih sangat rendah, sehingga pemerintah terpaksa mengizinkan impor daging dan susu. Sektor produksi peternakan harus melakukan antisipasi peningkatan konsumsi tersebut, terutama untuk menjamin ketahanan pangan dan menghindarkan pengurasan cadangan devisa negara untuk impor daging dan susu yang sebenarnya tidak perlu. Sistem peternakan domestik yang ada sekarang dinilai akan sulit melakukan antisipasi terhadap keadaan dan perubahan yang akan terjadi, sehinga diperlukan suatu tindakan restrukturisasi industri peternakan ke arah suatu sistem yang diharapkan. Sampai saat ini belum ada rumusan arah pembangunan peternakan dan efektivitas program-program pembangunan peternakan tidak atau belum jelas ke mana arahnya. Dalam kaitan itu, khusus untuk subsektor peternakan, perlu dirancang suatu gagasan tentang bagaimana bentuk peternakan harapan di masa depan dan langkah- langkah apa yang dibutuhkan untuk mewujudkannya. Tulisan ini bertujuan menyampaikan gagasan tersebut dengan melakukan analisis review dan sintesis hasilhasil penelitian sosial ekonomi peternakan yang pernah dilakukan.
\end{abstract}

Kata kunci : struktur peternakan, produksi, konsumsi, daging, susu

\section{PENDAHULUAN}

Program Pendidikan Masyarakat dan Pembangunan pertanian mempunyai beberapa sasaran utama yakni meningkatkan ketahanan pangan, mengurangi kemiskinan dan meningkatkan kesejahteraan petani. Program-program ini sangat jelas sejalan dengan permasalahan yang dihadapi dalam negeri, antara lain kejadian rawan pangan yang semakin meluas, sekitar 40 juta orang hidup dalam kemiskinan dan kehidupan sosial ekonomi petani yang masih belum menjamin mereka untuk dapat membangun daya saing produksi yang tinggi dan memanfaatkan keunggulan komparatif yang dimiliki. Perkembangan produksi pertanian khususnya tanaman pangan masih belum stabil, laju pertumbuhan produksi bergerak mengalami stagnasi, seakan-akan tidak lagi mampu meningkat. Pada sisi lain, laju konsumsi pangan sebagian masyarakat yang berpendapatan menengah dan tinggi bergerak lebih cepat, sehingga menciptakan gap konsumsi. Indonesia mengimpor komoditas pangan dalam jumlah relatif besar seperti beras, jagung, kedelai, daging dan susu untuk mengisi gap permintaan konsumsi tersebut.

Khusus subsektor peternakan yang selama ini kurang mendapat perhatian karena pemerintah lebih fokus pada usaha peningkatan beras mulai menggigit perekonomian nasional. Populasi ternak utama seperti sapi, kerbau dan kambing mengalami pengurasan yang terus meningkat setiap tahun. Pengurasan yang terus berlangsung ini mengancam keberlanjutan produksi hasil ternak dalam negeri, sehingga dikuatirkan jumlah impor terus meningkat. Statistik Peternakan (1995 
dan 2006) memperlihatkan bahwa 25 persen produksi daging dalam negeri berasal dari impor sedangkan Direktorat Peternakan tahun 2007 melaporkan bahwa Indonesia terpaksa impor daging 37,2 persen (Direktorat Jenderal Peternakan, 2007). Hal ini diperlihatkan oleh peningkatan impor ayam broiler dan jumlah sapi bakalan yang akan digemukkan dalam negeri telah mencapai angka fantastis yakni

450 ribu ekor. Perkembangan impor berbagai jenis ternak untuk tujuan meningkatkan produksi disertai dengan peningkatan impor bahan baku pakan sehingga Indonesia sebenarnya hanya mendapat nilai tambah dari tenaga kerja. Pada sisi lain kita akan selalu menghadapi ancaman wabah Avian Influenza, Antrax, Mulut dan Kuku, dan Sapi Gila.

Pertumbuhan ekonomi Indonesia diramalkan akan terus meningkat pada tahun-tahun mendatang, dan pertumbuhan ini akan memacu peningkatan konsumsi. Sektor produksi subsektor peternakan harus melakukan antisipasi peningkatan konsumsi tersebut, terutama untuk menjamin ketahanan pangan dan menghindarkan pengurasan cadangan devisa negara untuk impor daging dan susu yang sebenarnya tidak perlu. Sistem peternakan domestik yang ada sekarang dinilai akan sulit melakukan antisipasi terhadap keadaan dan perubahan yang akan terjadi, sehinga diperlukan suatu tindakan restrukturisasi industri peternakan ke arah suatu sistem yang diharapkan.

Kita sampai saat ini belum merumuskan arah pembangunan peternakan dan efektivitas program-program pembangunan peternakan tidak atau belum jelas kemana arahnya. Dalam kaitan itu, khusus untuk subsektor peternakan, perlu dirancang suatu gagasan tentang bagaimana bentuk peternakan masa depan yang diharapkan dan langkah-langkah apa yang dibutuhkan untuk mewujudkannya. Tulisan ini bertujuan menyampaikan gagasan tersebut dengan melakukan analisis review dan sintesis hasil-hasil penelitian sosial ekonomi peternakan yang pernah dilakukan.

\section{PERMASALAHAN DAN TANTANGAN}

Tulisan berikut ini merupakan review permasalahan dan tantangan pembangunan peternakan dari hasil-hasil penelitian Adnyana et al. (2019), Pembudi (1995), Yusdja dan Pasandaran (1994), Yusdja et al. (2002) dan Yusdja et al. (2020). Penulisan review ini dalam konteks membangun gagasan peternakan masa depan.

\section{Globalisasi Ekonomi}

Dua lingkungan strategis, yang patut mendapat perhatian dalam kerangka perkembangan industri agribisnis ternak dalam negeri adalah perubahan globalisasi dan permintaan pangan hasil ternak dalam negeri. Perubahanperubahan tersebut dapat memberikan keuntungan atau sebaliknya, akan sangat tergantung pada bagaimana sikap kita dalam mengelola pembangunan. Misalnya, mempertahamkam kebijakan pengembangan industri agribisnis yang sangat tergantung pada impor, maka kita membangun suatu industri yang rawan terhadap perubahan ekonomi global yang secara keseluruhan diluar kemampuan kita mempengaruhi perubahan tersebut. Dampak globalisasi dapat dikurangi dengan menegakan azas kemandirian dalam usaha dan memanfaatkan keunggulan komparatif sehingga memungkinkan Indonesia berperan dalam pasar dunia. 
Perlu dipahami bahwa sebagian besar negara-negara mempunyai peluang besar untuk memproduksi hasil-hasil ternak sehingga dapat dikatakan bahwa produksi ternak merupakan komoditas dunia, baik di negara maju maupun di negara berkembang. Artinya, pasar dunia untuk ternak dan hasil ternak kemungkinan dapat diisi oleh banyak negara. Indonesia adalah salah satu negara pertanian yang mempunyai peluang besar mengisi pasar dunia dengan hasil-hasil peternakan. Namun demikian, Indonesia belum dapat memanfaatkan peluang tersebut, bahkan dalam percaturan dunia masih merupakan negara konsumen hasil-hasil ternak. Sementara dari sisi pembangunan peternakan, Indonesia adalah negara yang sangat tergantung terhadap impor input teknologi peternakan untuk menggerakkan proses produksi dalam negeri dan untuk memenuhi kebutuhan yang tidak dapat dipenuhi dalam negeri.

Industri peternakan yang mempunyai ketergantungan tinggi pada bahan baku dan teknologi impor membawa berbagai ancaman dalam negeri. Seperti yang dialami dalam masa krisis moneter, yang telah memporak porandakan industri ayam ras dan sapi potong. Ancaman lain bisa datang dari negara eksportir teknologi tersebut khususnya jika mereka mendapat gangguan dalam negeri atau hubungan bilateral. Dalam hal ini, setiap saat negara tersebut dapat menghentikan ekspor teknologi. Seperti kasus wabah flu burung, setiap negara yang terkena epidemi akan menghentikan ekspor bibit Grand Parent Stock (GPS) unggas ke Indonesa, maka dalam masa satu tahun industri ayam ras dalam negeri akan bangkrut. Atau, jika Australia mendapat masalah cuaca, sehingga mereka terpaksa menghentikan ekspor sapi bakalan ke Indonesia maka dalam 3 tahun, akan terjadi kepunahan ternak sapi lokal. Demikian juga dengan ancaman kesulitan impor susu, dapat memberikan dampak kelaparan pada jutaan bayi. Ketergantungan pada impor jika tidak ditunjang oleh usaha-usaha membangun kemandirian akan mendorong ketergantungan semakin mendalam dan sulit dipecahkan.

Pada sisi ekspor, Indonesia mempunyai peluang besar mengisi pasar ternak hidup, daging, telur dan susu. Indonesia dianggap sebagai negara produsen yang aman karena produk ternak yang masih murni alami, dan bebas penyakit mulut dan kuku. Sampai saat ini ekspor hasil perternakan Indonesia relatif kecil dibandingkan nilai impor, tetapi tetap menggembirakan karena ekspor terus mengalami pertumbuhan 17 persen per tahun. Posisi Indonesia sebagai eksportir ternak sebenarnya sangat diharapkan oleh negara-negara Islam dunia. Mereka membutuhkan 5 juta ekor kambing setiap tahun dan berharap Indonesia dapat mengisi sebagian kebutuhan tersebut. Jika Indonesia mampu mengisi 5 persen saja dari kebutuhan tersebut atau sekitar 250 ribu ekor merupakan permulaan yang baik. Selain itu, kerjasama dengan negara-negara Islam perlu dikembangkan terutama dalam hal pengadaan dan pemotongan ternak untuk kebutuhan ibadah haji. Pengadaan dan pemotongan ternak dapat dilakukan di Indonesia, sehingga mengurangi beban negara Arab Saudi dalam membagikan daging korban yang melimpah (Yusdja et al., 2004).

Peluang ekspor daging ke Malaysia, Brunei Darussalam sangat besar, karena masyarakat negeri ini sangat menggemari daging sapi bali dibandingkan daging sapi hibrid. Betapapun kecilnya permintaan kedua negara tersebut, Indonesia harus berusaha memenuhinya, sebagai satu langkah menuju langkah besar dalam meningkatkan daya saing agribisnis ternak. Sementara itu, ekspor ayam ras terlihat terus berkembang sehingga memperlihatkan peluang lain yang 
harus di raih. Peluang ekspor lain, adalah pakan HMT (Hijauan Makanan Ternak) yang berlimpah dalam negeri untuk tujuan Australia. Australia pernah menjajaki kemungkinan impor HMT dari Indonesia terutama pada musim kemarau panjang yang melanda negara itu, namun Indonesia belum bisa merespon peluang tersebut. Padahal, Indonesia adalah negara pengimpor sapi bakalan terbesar dari Australia, sehingga mempunyai insentif besar untuk mendapatkan peluang kerjasama dengan Australia.

\section{Masalah Umum Program pendidikan Masyarakat dan Pembangunan Peternakan Masa depan}

Struktur industri peternakan untuk semua komoditas ternak domestik sebagian besar (60-80 persen) tetap bertahan dalam bentuk usaha rakyat. Usaha rakyat mempunyai ciri-ciri antara lain tingkat pendidikan peternak rendah, pendapatan rendah, penerapan manajemen dan teknologi konventional, lokasi ternak menyebar luas, skala usaha relatif kecil serta pengadaan input utama yakni HMT yang masih tergantung pada musim, tenaga kerja keluarga, penguasaaan lahan HMT yang terbatas, produksi butir-butiran terbatas dan sebagian tergantung pada impor.

Faktor penghambat utama bagi perkembangan peternakan rakyat adalah ketersediaan HMT dan butir-butiran. Indonesia memproduksi HMT untuk ruminansia secara berlimpah, tersebar diseluruh wilayah, namun sebagian besar terbuang. Pada sisi lain peternak membutuhkan tenaga kerja untuk mencari HMT. Pengadaan input yang tidak efektif seperti itu dilakukan oleh jutaan peternak. Jika tidak ada lembaga jasa penyedia HMT, maka kesulitan tenaga kerja akan menjadi pembatas pengembangan ternak dan skala usaha untuk ternak sapi potong, sapi perah, kerbau, kambing di tingkat peternak. Mereka tidak mempunyai modal untuk membayar tenaga upahan. Hasil penelitian memperlihatkan bahwa peningkatan skala usaha melebihi kemampuan ketersediaan tenaga kerja justru membuat usaha menjadi tidak efisien.

Atas dasar itu, ketersediaan lembaga pelayanan pengadaan HMT oleh pihak ketiga akan mendorong peningkatan skala usaha dari minimal 3 ekor menjadi maksimal 30 ekor dan peningkatan ini pada akhirnya meningkatkan produksi peternakan dan akan terjadi peningkatan produksi lebih dari 200 persen. Pelayanan pengadaan pakan dapat disamakan dengan pengadaan air irigasi untuk tanaman pangan. Selama ini, ketiadaan pelayanan HMT oleh pihak ketiga khususnya oleh pemerintah telah terbukti tidak mendorong perkembangan industri peternakan. Usaha tradisional tetap tradisional dan tidak ada kemajuan dalam usaha pembibitan. Jika pelayanan itu tersedia maka diharapkan dari 2 juta peternak rakyat, 10 persen dapat bangkit menjadi pengusaha-pengusaha skala menengah dan 2 persen menjadi usaha skala besar, dan sisanya adalah usaha rakyat dengan skala usaha lebih dari 10 ekor per RT. Pengembangan peternakan yang berdayasaing haruslah dimulai dari sini.

Faktor penghambat kedua adalah teknologi bibit. Hampir semua jenis ternak domestik tidak mendapat sentuhan teknologi pembibitan yang intensif. Mutu ternak semakin buruk karena ternak yang baik selalu terpilih untuk dipotong. Penelitian-penelitian skala kecil tentang pembibitan telah banyak dilakukan tetapi belum dapat disosialisasikan dalam skala besar. Dalam hal ini komunikasi antara Badan Litbang Pertanian maupun Perguruan Tinggi dengan 
para perumus kebijakan di Direktorat Jenderal Peternakan belum terjalin dengan baik. Hambatan lain, adalah bahwa peternak rakyat tidak mempunyai insentif nyata dalam mengadopsi teknologi baru, apalagi pemanfaatan teknologi baru selalu disertai dengan peningkatan biaya dan perbaikan manajemen. Pada sisi lain, peternak melakukan budidaya dengan untung-untungan dan biaya mendekati nol.

Untuk merespon permasalahan bagaimana kebijakan yang diperlukan untuk meningkatkan manfaat dan nilai tambah sumberdaya ternak domestik. Banyak gagasan berkembang, antara lain mendorong investor skala besar untuk mengambil alih usaha rakyat itu. Namun, pengusaha besar lebih menyukai menggunakan manajemen dan teknologi impor seperti apa yang dilakukan perusahaan feedlot sapi potong, perusahaan peternakan ayam modern, perusahaan sapi perah dan babi. Namun demikian, pemerintah tidak dapat berpaling dari sumberdaya ternak domestik yang bernilai trilyunan rupiah tersebut dan yang sudah terbukti berperan besar dalam perekonomian perdesaan. Untuk jangka menengah pemerintah diharapkan menjadi satu-satunya investor bagi menciptakan pelayanan bagi pengembangan usaha rakyat. Pemerintah merupakan lembaga yang saat ini layak mengantarkan industri peternakan rakyat pada pintu gerbang siap landas.

Masalah ketiga berkaitan dengan agroindustri peternakan. Kebijakan pembangunan agroindustri peternakan selama ini secara umum tidak terkait ke belakang yakni pada budidaya peternakan dalam negeri. Sebagai contoh, industri pengolahan susu, sebagian besar menggunakan input dari negara asal, industri peralatan rumah tangga dan aksesories mengimpor kulit dari berbagai negara dan industri perhotelan membutuhkan daging asal impor. Dengan demikian pertumbuhan agroindustri selama ini tidak turut mendorong pertumbuhan subsektor peternakan.

\section{PERAN PROGRAM PENDIDIKAN MASYARAKAT DAN PETERNAKAN MASA DEPAN}

Berdasarkan gambaran budidaya, perkembangan produksi dan konsumsi di atas, maka timbul pertanyaan sebaiknya seperti apa peternakan Indonesia masa depan?. Terlepas dari persoalan apapun gagasan yang berkembang tentu bentuk peternakan masa depan tersebut harus dapat menjawab beberapa tantangan yang dihadapi saat ini dan ke depan. Tantangan itu antara lain kemampuan memberikan dukungan pada persediaan pangan dalam negeri, memberikan dukungan besar bagi perkembangan industri dan memanfaatkan keunggulan komparatif sebesarbesarnya sehingga industri mempunyai daya saing dalam pasar global. Industri peternakan masa depan harus juga mempunyai kekuatan yang tinggi terhadap perubahan cuaca global, peningkatan keuntungan dan manfaat bagi pengusaha ternak dan jaminan produksi makanan yang aman dan sehat melalui sistem peternakan yang tepat (Anonimous. 2001). Secara praktis peternakan masa depan harus mempunyai ketangguhan berlandaskan iptek dan padat modal.

Peternakan yang kita harapkan adalah peternakan yang dapat memberikan peran paling tidak dalam beberapa hal berikut:

a. Menyediakan pangan asal ternak berdasarkan ASUH (Aman, Sehat, Utuh dan Halal) dengan harga yang terjangkau oleh banyak masyarakat.

b. Menyediakan bahan baku industri seperti industri makanan, industri kerajinan, industri pakan ternak. 
c. Mengembangkan industri hiburan antara lain pariwisata seperti: pacuan, adu ketangkasan, karapan sapi dan sebagainya.

d. Menjadi salah satu media atau agen yang aktip atau diaktipkan oleh manusia dalam kerangka menjaga ekosistem.

Paradigma pembangunan peternakan yang kita lakukan selama ini berdasarkan pada tujuan meningkatkan kesempatan kerja berdasarkan UU Peternakan 1967. Undang-undang ini menyatakan bahwa peternakan merupakan usaha rakyat. Melihat fungsi peternakan yang dibahas di atas, maka kerangka berpikir seperti itu tidak lagi sesuai. Kita justru membutuhkan pembangunan peternakan dengan teknologi tinggi dan padat modal, sehingga produk peternakan dapat dihasilkan dengan biaya jauh lebih rendah. Jika biaya produksi jauh lebih rendah maka akan mendorong permintaan hasil ternak yang tinggi khususnya subsektor industri kecil dan skala menengah seperti industri makanan dan kerajinan rakyat. Peningkatan permintaan ini akan mendorong kesempatan kerja dan permintaan tenaga kerja. Oleh karena itu, peternakan yang kita harapkan bukanlah peternakan yang berperan langsung sebagai penampung kesempatan kerja tetapi mempunyai dampak tidak langsung melalui perkembangan subsektor industri.

Dari sisi teori ekonomi, khusus bagi yang percaya bahwa alokasi sumberdaya lebih efisien jika diatur oleh mekanisme pasar, sedangkan pemerintah hanya melakukan pengawasan maka sebenarnya pemerintah tidak perlu membuat disain bagaimana bentuk peternakan masa depan. Jika disain dibuat dan kemudian diimplementasikan, maka dapat dipastikan bahwa pemerintah akan melakukan intervensi langsung secara intensif sebagai suatu hal yang tidak dapat dihindarkan. Kita menyadari bahwa intervensi pemerintah secara langsung tidak lagi sesuai dengan konsep pembangunan. Indonesia telah mempunyai pengalaman yang sangat mahal ketika melakukan intervensi langsung dalam mengarahkan pembangunan dan perkembangan usaha ayam ras dan usaha sapi perah ke arah bentuk usaha rakyat. Hasilnya, pemerintah tidak bisa melawan arus mekanisme pasar.

\section{ARAH PROGRAM PENDIDIKAN MASYARAKAT DAN KEBIJAKAN PEMBANGUNAN MENUJU SISTEM SOSIAL EKONOMI PETERNAKAN YANG DIHARAPKAN}

Program pendidikan dan Peternakan komersil di Indonesia pada umumnya terbatas pada usaha peternakan dengan bibit impor seperti ayam ras, feedlot sapi potong, sapi perah dan babi. Kehadiran ternak unggas impor hampir mencapai 70 persen dari ternak unggas domestik, untuk sapi potong sekitar 15 persen, sapi perah 60 persen dan babi sekitar 20 persen. Dengan kata lain, hampir sebagian besar peternakan komersil di Indonesia semuanya menggunakan bibit impor. Pengembangan peternakan ayam ras sebagai contoh, merupakan industri peternakan yang relatif sangat maju dengan fasilitas dan infrastruktur yang lengkap. Hanya disayangkan bahwa komponen utama budidaya ayam ras terutama bibit dan pakan sangat tergantung pada impor. Pada sisi lain, pengembangan peternakan komersil dengan menggunakan ternak domestik sangat terbatas, karena alasan teknologi dan produktivitas bibit masih sangat rendah, produktivitas tidak berimbang dengan jumlah pakan yang dikonsumsi.

Program Industri peternakan menurut struktur pengusahaan, besaran 
modal yang digunakan dan manajemen yang diterapkan pada umumnya dapat dikelompokan dalam 5 sektor sebagai berikut:

Sektor 1: Sistem Industri Terintegrasi (Industrial Integrated System)

Perusahaan peternakan yang masuk dalam kelompok ini melaksanakan manajemen intensif, modal relatif tinggi, input bibit dan pakan dihasilkan sendiri sedangkan produk pada umum untuk dikonsumsi oleh peternakan sektor 2 .

Sektor 2: Sistem Perusahaan Komersial

Perusahaan peternakan yang masuk dalam kelompok ini melakanakan manajemen intensif, modal relatif tinggi, manajemen biosekuriti relatif Moderat Sampai Tinggi sedangkan produksi langsung merupakan pangan, sedangkan input tergantung pada Sektor 1 atau impor.

Sektor 3: Sistem Peternakan Skala Kecil (Rakyat)

Perusahaan peternakan yang masuk dalam kelompok ini melaksanakan manaejemen intensif rendah, modal sangat rendah, produksi adalah pangan. Usaha pada sektor ini mempunyai ketergantungan pasar output dan input pada jasa pelayanan.

Sektor 4: Sistem Peternakan Tradisional (Perdesaan)

Pengelolaan ternak pada umumnya ekstensif dan kadang-kadang liar. Usaha ternak yang masuk dalam kelompok ini terdapat di perdesaaan dalam bentuk usaha sambilan (backyard farming).

Sektor 5: Sistem Peternakan Liar.

Merupakan hewan-hewan liar yang pada umumnya tidak memiliki tempat tinggal, hidup dalam alam secara bebas, pakan sangat tergantung pada alam. Hewanhewan liar dapat hidup subur pada habitatnya, tetapi hewan-hewan liar yang dipelihara oleh manusia diluar habitatnya pada umum berada pada wilayah pemukiman.

Tabel 1 memperlihatkan keragaan industri peternakan menurut sektor dan komoditas unggulan Departemen Pertanian yakni unggas(ayam ras, ayam buras dan itik), Sapi (Sapi potong, sapi perah dan kerbau) dan Kado (Kambing dan Domba). Tabel 1 memperlihatkan bahwa hanya ayam ras yang telah mengisi sektor 1, sementara sektor 2 sebagian besar diisi oleh ternak bibit impor, dan peternakan domestik mengisi sektor 3 dan 4 .

Tabel 1. Keragaan Industri Peternakan Menurut Sektor, 2020

Sektor

\begin{tabular}{lcccccc} 
& 1 & 2 & 3 & 4 & 5 \\
\hline Ayam Ras (impor) & $\sqrt{ }$ & $\sqrt{ }$ & $\sqrt{ } \sqrt{ }$ & $\sqrt{ }$ & - \\
Ayam Buras & - & - & $\sqrt{ }$ & $\sqrt{ } \sqrt{ }$ & $\sqrt{ }$ \\
Unggas Itik & - & - & $\sqrt{ }$ & $\sqrt{ } \sqrt{ }$ & $\sqrt{ }$ \\
Sapi Potong/Kerbau & - & $\sqrt{ }$ & $\sqrt{ }$ & $\sqrt{ } \sqrt{ }$ & - \\
Feedlot Sapi Impor & - & $\sqrt{ } \sqrt{ }$ & $\sqrt{ }$ & - & - \\
Sapi Perah (impor) & - & $\sqrt{ }$ & $\sqrt{ } \sqrt{ }$ & - & - \\
Kado (Kambing Domba) & - & - & $\sqrt{ } \sqrt{ }$ & $\sqrt{ } \sqrt{ }$ & - \\
\hline
\end{tabular}

Sumber: Dari berbagai Laporan Hasil Penelitian PSE-KP (2020-2021) Catatan: $\sqrt{ } \sqrt{ }=$ Banyak, $\sqrt{ } \sqrt{ }$ Sedang $\sqrt{ }=$ terbatas $O$ terbatas bersyarat 
Keragaan pada Tabel 1 tentulah bukan peternakan yang kita harapkan karena sudah terbukti tidak mempunyai kemampuan memainkan perannya sebagaimana dibahas di atas. Kemana arah perubahannya? Tabel 2 memperlihatkan keragaan industri peternakan yang kita harapkan, dengan arah kebijakan seperti berikut:

a. Industri Peternakan terutama dalam kerangka pemanfaatan ternak domestik harus didorong berkembang mencapai sektor 1 dan 2 .

b. Pengembangan ternak kecil seperti ayam buras dapat dilakukan oleh sektor 3, karena sektor 2 akan diisi oleh ayam ras.

c. Industri ayam ras diarahkan berkembang ke sektor 1 dan 2. Secara alami hal ini sudah terjadi. Diprediksi dalam masa 5 tahun ke depan sektor 3 dan 4 hampir tidak ada lagi.

d. Pemanfaatan ternak besar seperti sapi dan kerbau didorong berkembang pada sektor 2 dan 3, sedangkan pemanfaatan sapi impor ditiadakan (dalam jangka panjang).

e. Peternakan kambing dan domba diarahkan pada sektor 2 dan secara terbatas pada sektor 3. Hal ini berdasarkan pertimbangan, kado adalah ternak berukuran kecil, sangat mudah berkembang dan tahan terhadap manajemen yang buruk.

Tabel 2. Keragaan Industri Peternakan yang Diharapkan Menurut Sektor, 2020 Sektor

\begin{tabular}{|c|c|c|c|c|c|c|}
\hline & 1 & 2 & 3 & 4 & & 5 \\
\hline Ayam Ras & $\sqrt{ }$ & $\sqrt{ } \sqrt{ }$ & - & - & & \\
\hline Ayam Buras & $\sqrt{ } \sqrt{ }$ & - & $\sqrt{ } \sqrt{ } \sqrt{1}$ & $\sqrt{ }$ & & $\mathrm{O}$ \\
\hline Itik & $\sqrt{ } \sqrt{ }$ & - & $\sqrt{ } \sqrt{ }$ & & - & $\mathrm{O}$ \\
\hline Sapi Potong/Kerbau & $\sqrt{ }$ & $\sqrt{ } \sqrt{ }$ & $\sqrt{ } \sqrt{ }$ & & O & \\
\hline Feedlot Sapi Import & - & - & - & - & & \\
\hline Sapi Perah & $\sqrt{ }$ & $\sqrt{ } \sqrt{ }$ & $\sqrt{ }$ & - & & \\
\hline Kambing & $\sqrt{ } \sqrt{ }$ & $\sqrt{ } \sqrt{ }$ & $\sqrt{ }$ & $\sqrt{ }$ & & $\mathrm{O}$ \\
\hline Domba & $\sqrt{ } \sqrt{ }$ & $\sqrt{ } \sqrt{ } \sqrt{ }$ & $\sqrt{ }$ & $\sqrt{ }$ & & $\mathrm{O}$ \\
\hline
\end{tabular}

Catatan: $\sqrt{ } \sqrt{ }=$ Banyak, $\sqrt{ } \sqrt{\text { Sedang }} \sqrt{ }=$ terbatas $O$ terbatas bersyarat

\section{PROGRAM PENDIDIKAN MASYARAKAT DAN KEBIJAKAN MEWUJUDKAN PETERNAKAN YANG DIHARAPKAN}

Utuk mencapai keragaan pada Tabel 2 tentu tidak bisa dengan campur tangan langsung pemerintah, karena justru akan menyebabkan alokasi modal, waktu dan sumberdaya menjadi tidak efisien. Berdasarkan pengalaman masa lalu, dapat disimpulkan bahwa seharusnya peran pemerintah hanyalah terbatas pada pelayanan yang sedemikian rupa sehingga mekanisme pasar dapat bekerja. Mekanisme pasar khususnya dalam pembangunan peternakan domestik belum bergerak hingga saat ini karena berbagai simpul yang dibutuhkan belum tersedia. Pada kenyataannya, Indonesia telah membangun peternakan dalam masa 30 tahun terakhir namun belum mampu mendorong mekanisme pasar bekerja, sehingga peternakan bergeming sebagai peternakan tradisional. Pertanyaan penting mengenai hal ini adalah pelayanan seperti apa yang harus dilakukan pemerintah?. Ada tiga langkah strategis pelayanan, sebagai syarat keharusan, yang harus 
dilakukan pemerintah sebagai berikut:

1. Memperlakukan Ternak Sebagai Sumberdaya

a. Memperlakukan ternak sebagai sumberdaya, dalam pengertian bahwa ternak dapat punah dan tidak bisa dipulihkan jika ternak habis terpakai. Karena itu pemerintah harus berupaya keras mempertahankan dan mengembangkan sumberdaya sebagai sumber pertumbuhan produksi daging, susu dan telur.

b. Pengertian sumberdaya adalah bahwa ternak itu merupakan sumber genetis yang dapat diturunkan dan dikembangkan untuk kepentingan manusia. Dalam hal ini ternak sumberdaya berfungsi menghasilkan ternak komoditas dan ternak produk.

2. Menyediakan Infrasruktur Industri Peternakan

a. Menyediakan infrastruktur khususnya bagi penyediaan lahan dan pengairan bagi kemudahan memproduksi HMT (Hijauan Makanan Ternak). Penyediaan infrastruktur ini harus dalam bentuk investasi publik sebagaimana pembangunan irigasi untuk tanaman pangan.

b. Infrastruktur untuk pemanfaatan lahan dan air merupakan kontrain yang utama dalam pengembangan ternak karena sifat biologis yang terkandung. Tanpa pelayanan ini, maka investasi peternakan sulit berkembang dan karena industri peternakan akan tetap berbentuk tradisionil.

3. Melakukan Usaha Pengendalian Penyakit Ternak

a. Pengendalian penyakit ternak, antara lain menjaga kesehatan ternak dan mencegah penularan penyakit di antara ternak dan manusia termasuk di dalamnya produksi pangan asal ternak yang sehat dan aman (ASUH).

b. Pengendalian penyakit ternak pada masa mendatang merupakan isue yang sangat penting dalam perdagangan hasil peternakan dunia.

Jika pemerintah memberikan pelayanan dasar ketiga hal di atas, maka hal itu sudah merupakan langkah awal bagi menggerakkan pasar sehingga pelaku ekonomi bersedia mengalokasikan sumber daya alam dan kapital bagi pembangunan peternakan. Pada langkah selanjutnya, melalui mekanisme pasar dan pengawasan pemerintah dapat diciptakan peternakan masa depan yang dapat memainkan perannya seperti yang telah dibahas di atas. Pada akhirnya arah kebijakan pembangunan peternakan untuk meningkatkan kesejahteraan masyarakat yang sangat jelas. Kita menyarankan bahwa pemerintah tidak perlu berpikir panjang untuk mengeluarkan biaya yang relatif besar untuk menegakkan ketiga pelayanan di atas, karena mempunyai dampak jangka panjang bagi generasi mendatang.

Setelah syarat keharusan dipenuhi, maka untuk mempercepat pertumbuhan dan pengembangan peternakan perlu dipenuhi syarat kecukupan mencakup:

1. Undang Undang Peternakan yang Akomodatif

Undang-undang Peternakan 1967 tidak lagi sesuai dengan perubahanperubahan besar yang terjadi dalam dunia peternakan. Kita membutuhkan undangundang yang dapat menggerakkan dan melindungi baik terhadap kebijakankebijakan pemerintah, aktivitas investor dan masyarakat. Undang-Undang yang sesuai memberikan kekuatan pada pemerintah secara politis dalam memperoleh prioritas pembangunan peternakan. Pada sisi lain, undang-undang peternakan yang sesuai memberikan dampak positip kepada investor dalam subsektor peternakan, terutama dalam mendapatkan perlindungan hukum terhadap usaha dan investasi. 


\section{Program Pengembangan Iptek}

Pengembangan ilmu pengetahuan dan teknologi tentu tidak dapat dihindarkan dan ini sangat terkait dengan pembangunan sumberdaya manusia. Penelitian peternakan harus mempunyai kerangka yang jelas dalam mewujudkan sistem peternakan yang diharapkan. Dalam hal ini penelitian peternakan mempunyai fungsi strategis karena berfungsi memenuhi syarat keharusan dalam pengembangan sumberdaya ternak. Sasaran penelitian peternakan jelas kepada perbaikan mutu genetis ternak, pemanfaatan bahan baku pakan dalam negeri seluas-luasnya dan sistem manajemen budidaya yang efisien. Pengembangan ilmu pengetahuan untuk mendukung pembangunan dan pengembangan peternakan harus juga mempertimbangkan keserasian dengan konsep alam yakni ekosistem. Peternakan berdasarkan ekosystem menjamin keberlanjutan pertumbuhan produksi. Suatu bentuk pengembangan sistem peternakan yang ekologis adalah integrasi wilayah-wilayah perkebunan dengan usaha penggemukan ternak ruminansia seperti sapi, kambing dan domba. Contoh lain adalah pengembangan peternakan berazaskan zero waste di mana ternak berfungsi sebagai media bioindustri bagi merubah hijauan sisa tanaman menjadi produk berguna. Pada tahapan lanjut, ternak dapat menghasilkan pupuk anorganik untuk kebutuhan tanah dan tanaman. Sistem zero waste ini dapat diterapkan dalam skala kecil (kawasan) maupun skala regional atau nasional dan tentu dibutuhkan pembangunan kelembagaan atau organisasi komersil bagi memungkinkan hal itu terjadi.

3. Program Penyediaan Kawasan

Suatu kawasan peternakan mencakup sebuah wilayah yang mempunyai kerapatan penduduk jarang, wilayah kurang subur, wilayah yang kemungkinan besar tidak akan dijadikan wilayah pemukiman, merupakan wilayah lahan kering, dekat dengan sumber air atau air dapat dialirkan ke kawasan itu. Pengadaan air dikawasan- kawasan tersebut merupakan investasi publik. Pada langkah selanjutnya, Pemerintah sebaiknya memetakan seluruh kawasan yang memenuhi syarat yang terdapat di seluruh Indonesia dan memberikan arahan kawasankawasan mana yang dicadangkan bagi peternakan.

Pada wilayah yang dicadangkan itu, pemerintah menyediakan pelayanan infrasruktur seperti jalan raya (jika belum ada), saluran air irigasi bagi penggunaan pengairan HMT dan pemeliharan ternak. Usaha pemetaan ini akan sangat membantu investor sehingga mereka merasa mendapat perlindungan dan keyakinan akan keberhasilan usaha. Selain itu, diperlukan pula pelayanan dalam bentuk investasi publik yang lain yakni pembangunan pusat-pusat pengendalian penyakit. Pada sisi lain, berdasarkan kriteria kawasan tersebut di atas, hanya sebagian kecil pulau Jawa dapat menyediakan kawasan semacam itu, antara lain pulau Jawa bagian selatan. Namun, di luar Jawa dapat ditemukan lebih banyak kawasan.

4. Program Pelayanan Kredit dan Pembiayaan

Untuk mempercepat perkembangan sektor 2 dan 3 maka pemerintah dapat memberikan palayanan kredit dengan fasilitas khusus serta pembiayaan untuk meningkatkan kemampuan modal peternakan sektor 3. 


\section{PENUTUP}

Sistem Program pendidikan peternakan yang kita harapkan pada masa depan tentu belum tentu jelas ujutnya seperti apa dan kalaupun jelas tidak bisa dipaksakan melalui tindakan tangan besi. Apa yang dapat kita rencanakan adalah bagaimana fungsi peternakan masa depan yang kita harapkan dan bagaimana arah kebijakan yang diperlukan untuk mewujudkannya. Jika itu jelas, maka akan konkrit pula peran berbagai pihak seperti pemerintah, investor dan masyarakat. Pembangunan akan berlangsung cepat jika semua pihak berpartisipasi secara bebas menurut perannya masing- masing di atas roadmap pembangunan peternakan yang telah disepakati. Dalam kerangka ini, kita jelas membutuhkan Undang Undang Peternakan yang mendukung apa yang telah dibahas di atas.

\section{DAFTAR PUSTAKA}

Adnyana MO., Gunawan M., Ilham N., Saktyanu KD., Kariyasa K., Sadikin I., dan Djulin AM. 1996. Prospek dan Kendala Agribisnis Peternakan Dalam Era Perdagangan Pasar Bebas ; Pusat Penelitian Sosial Ekonomi Pertanian ; Badan Penelitian dan Pengembangan Pertanian.

Direktorat Jenderal Peternakan. 2007. Program Percepatan Pencapaian Swasembada Daging Tahun 2010. Direktorat Jenderal Peternakan. Departemen Pertanian. Jakarta.

Pambudi. R. 1995. Industrialisasi Peternakan dan Peranan UndangUndang/Peraturan Sebagai Instrumen Kebijakan. Fakultas Peternakan IPB. Bogor.

Statistik Peternakan. 1995. Statistik Peternakan. Buku Data Statistik Peternakan. Direktorat Peternakan Departemen Pertanian. Jakarta.

Statistik Peternakan. 2006. Statistik Peternakan 2006. Direktorat Jenderal Peternakan. Departemen Pertanian Jakarta.

Yusdja. Y., R. Sayuti., B. Winarso., I. Sodikin dan C. Muslim. 2004. Pemantapan Program Dan Strategi Kebijakan Peningkatan Produksi Daging Sapi. Laporan Hasil Penelitian. Pusat Analisis Sosial Ekonomi dan Kebijakan Pertanian. Bogor.

Yusdja. Y, N. Ilham dan S. Wahyuning. 2002. Outlook Peternakan 2002. Laporan Hasil Penelitian dan Pengembangan Sosial Ekonomi Pertanian. Bogor.

Yusdja Y., Malian H., Winarso B., Sayuti R. dan Bagyo AS. 2001. Analisis Kebijaksanaan Pengembangan Agribisnis Komoditas Unggulan Peternakan; Pusat Penelitian dan Pengembangan Sosial Ekonomi Pertanian; Badan Litbang Pertanian.

Yusdja, Y dan E. Pasandaran. 1994. Pokok-Pokok Pikiran Mengenai Kebijaksanaan Pengembangan Agribisnis Peternakan. Prosiding Sains dan Teknologi Peternakan. Balitnak Ciawi Bogor. 